\title{
New species and new record of the genus Uvitellina Witenberg, 1923 (Cyclocoelidae: Haematotrephinae) infecting Black-Winged Stilt, Himantopus himantopus (L.) (Charadriiformes: Recurvirostridae) in Sindh, Pakistan
}

\author{
Farooque Ali Hattar, Saima Naz* and Nadir Ali Birmani
}

Advance Parasitology Research Laboratory (APRL), Department of Zoology, University of Sindh, Jamshoro-76080, Sindh-Pakistan

*Corresponding author's email: symanaz@hotmail.com

Citation

Farooque Ali Hattar, Saima Naz and Nadir Ali Birmani. New species and new record of the genus Uvitellina Witenberg, 1923 (Cyclocoelidae: Haematotrephinae) infecting Black-Winged Stilt, Himantopus himantopus (L.) (Charadriiformes: Recurvirostridae) in Sindh, Pakistan. Pure and Applied Biology. Vol. 9, Issue 1, pp320-331. http://dx.doi.org/10.19045/bspab.2020.90037

Received: 06/08/2019 Revised: 30/10/2019 Accepted: 01/11/2019

Online First: 06/11/2019

\section{Abstract}

During the helminthic investigation of wading birds of Sindh, the Black-winged stilt, Himantopus himantopus (L., 1758) (Charadriiformes: Recurvirostridae) was examined to update the trematode fauna of Sindh, Pakistan. The trematodes worms were recovered from the body cavity of the host and identified as species of the genus Uvitellina Witenberg, 1923; total 22 birds were examined in which 19 birds were found infected with 56 specimens of three species under the genus Uvitellina. The three species were identified as $U$. vanelli (Rudolphi, 1819) and U. pseudocotylea Witenberg, 1923 as new host and country record, and $U$. sindhiensis was introduced as species novum, which was named on its type locality, Sindh province, Pakistan.

Keywords: Himantopus himantopus; new species; Pakistan; Sindh; taxonomical study; Uvitellina

\section{Introduction}

The Black-winged stilt Himantopus himantopus (Linnaeus, 1758) is a common long legged, medium sized, wading bird, belonging to avian order Charadriiformes and family Recurvirostridae. It is cosmopolitan and frequently found in Sindh near aquatic and marshy water bodies, mostly in summer to spring. It feeds on a wide range of food, including aquatic beetles, bugs, worms, dipterans larvae, crustaceans, snails, tadpoles, small fish, etc. which make highly possible the transference of helminthic infection from primary host to the bird as secondary host [1-5].

In the present study of helminthological investigation of aquatic birds of Sindh, Pakistan, the black-winged stilt was examined for its parasitic infection in the region, especially with reference to the 
trematode infection. Previously, there has no significant work been done on this bird host, except some sporadic investigations [6]. The present work is a contribution towards the addition of Uvitellina species that has been made in the trematodes fauna of wading birds found in Sindh, Pakistan.

\section{Materials and methods}

For helmintholigical examination, 22 birds of Black-winged stilts were collected and examined for their trematode infection from different localities of Sindh during November 2017 to May 2018. Birds were anesthetized with chloroform and autopsy was carried out. All the visceral organs, intestine and body cavity of each bird were thoroughly examined under stereo microscope. The trematodes under present study were recovered from the body cavity and were isolated with the help of soft brush and washed with $0.9 \%$ saline water. The trematodes were then left in saline water to inflate for 10-15 minutes; these were shifted to $10 \%$ ethanol and were processed for permanent mounts in Canada balsam through dehydration in $10-70 \%$ ethanol. At this stage the specimens were stained with borax carmine solution; further dehydration was done by $70-90 \%$ and absolute ethanol consecutively and fixed with clove oil and xylol for 1-2 minutes respectively. The mounting was carried out in Canada balsam at final stage. The illustration and measurements were made by using OlympusUDA drawing tube attachment and oculomicrometer respectively; measurements were taken in millimeters (mm). Specimens were deposited in the Advanced Parasitology Research Laboratory-Museum of Parasitology (APRLMP), Department of Zoology, University of Sindh, Pakistan.

\section{Results}

Uvitellina vanelli (Rudolphi, 1819)

(Digenea: Cyclocoelidae:

Haematotrephinae)

Figures 1-3, Table 1.
U. tageri Yamaguti, 1933; U. keri Yamaguti, 1933.

\section{Type Host:}

Vanellus vanellus Northern lapwing (Charadriiformes: Charadriidae).

\section{Material examined}

Present

Host:

Himantopus himantopus Black-winged stilt. Locality: Sindh (District Naushehro Feroze), Pakistan.

Date of collection: 20-i-2018.

Site of infection: Body Cavity.

No of parasites recovered: 24 out of 8 birds.

Prevalence: $87.5 \%$

Intensity: 3.42 .

Status: New locality and new host record.

\section{Description}

Body is long and narrow to lanceolate, with tapered anterior end, measuring 15.07 (15.57-14.56) long and 2.87 (2.90-2.84) wide at center of the body; ventral sucker absent; oral sucker well developed, wider than long measuring 0.14 (0.14-0.15) long and 0.39 (0.49-0.29) wide; pharynx sufficiently large, 0.34 (0.30-0.39) long and 0.0.41 (0.40-0.42) wide; caeca wide and simple, united at posterior; uterine loops invading over caeca; vitellaria confluent posteriorly in form of small follicles; ovary round and pretesticular, with $0.41(0.38-0.45)$ long and $0.43(0.45-0.42)$ wide; testes trigonal and tandem, anterior testes measuring $0.86(0.83$ $0.90)$ long and $0.87(0.85-0.88)$ wide, posterior tests $0.84(0.90-0.79)$ long and 0.81(0.85-0.78) wide; eggs reniform with very thin and fragile shell, measuring 0.23 (0.30-0.23) long and 0.1(0.11-0.09) wide.

\section{Remarks}

The present species, $U$. vanelli was first introduced by Rudolphi in 1819 [7], which was recovered from its type host, Vanellus vanellus, under the name, Monostoma vanelli. This was later redesribed by Bashkirova [8] and followed the nomenclature of Rudolphi [7], however Dubois [9] described it under the genus 
Uvitellina and proposed synonymies $U$. keri Yamaguti, 1933 and $U$. tageri Yamaguti, 1933 with $U$. vanelli, because both species are identical in particular characteristics to this species. In 1971, Yamaguti [10] illustrated it as Haematotrephus, Uvitellina kaniharensis (first proposed by Gupta [11], considered this species synonymous to Cyclocoelum (Haematotrephus) vanelli [7, 9]. Yamaguti $[10,12]$ suggested that this species has genital pore is post pharnyngeal, vitalline field extend posteriorly, ovary pretesticular hence, assigned it in genus Uvitellina, having uterine coil invading lateral side of caeca and posteriorly most uterine coils touch the anterior to anterior testis. The present species also recovered from other host birds, which played the role of its definitive host, including Tringa flavipes [13], Vanellus cinereus [12], Tringa melanoleuca [14]; presently recovered from Himantopus himantopus. This species is verified on the basis of description, measurements, body size and shape which is large, longiform, genital pore is postpharyngeal, uterine coil is over reaching caeca, vitallaria extend laterally to the posterior, ovary pre-testicular, testis are tandem and trigonal, above cirus sac, hence this species has been identified as Uvitellina vanelli. However this species was recovered for the first time from the present host in Sindh region, therefore making new host and new locality on record.

Uvitellina pseudocotylea Witenberg, 1923

(Digenea: Cyclocoelidae:

Haematotrephinae)

Figures 4-6, (Table 1).

U. pseudocotylea Witenberg, 1923.

Type Host

Himantopus candidus Long-legged Plover.

Material examined

Present Host: Himantopus himantopus Black-winged stilt (Charadriiformes:

Recurvirostridae).

Locality: Sindh (District Dadu), Pakistan.
Date of collection: 21-iii-2018.

Site of infection: Body Cavity.

No. of parasites recovered: 18 out of 6 birds.

Prevalence: $75 \%$.

Intensity: 6.

Description

Body longiform, anteriorly tapered and posteriorly broad, measuring 14.11 (16.5411.68) long and $2.21(2.52-1.90)$ wide at the center of the body; oral sucker well developed with $0.25(0.23-0.28) \times 0.26(0.30$ $0.28)$; cirus pouch measures $0.46(0.57-0.35)$ $\times 0.20(0.28-0.13)$; pharynx large and wide with $0.67(0.35-0.32) \times 0.42(0.42-0.43)$; ovary rounded, measured $0.43(0.40-0.46) \times$ $0.46(0.42-0.50)$; testes tandem and trigonal, anterior testis smaller than posterior both measured $0.67(0.66-0.69) \times 0.56(0.59-0.54)$ and $0.8(0.78-0.82) \times 0.65 \quad(0.61-0.69)$ respectively; egg soft with delicate shell, measuring $0.16(0.21-0.11) \times 0.05(0.11-$ 0.08 ) in size, more or less oval in shape.

\section{Remarks}

Present species of the genus Uvitellina was recovered from Black-winged stilt whereas it has also been previously recovered from Charadrius dubius (Little ringed plover) and C. placidus (Long billed plover (Charadriidae). Presently, it has been recovered from the body cavity of host and is verified on the basis of description, measurements, body size, which is large lanceolate and uterine loops is over reaching the ovary, slightly touching and crossing the side of ovary, vitallaria extend laterally posterior, ovary pre-testicular spherical, located at opposite to the posterior testis, testis are tandem and trigonal, hence the species was identified as $U$. pseudocotylea. However this species has been recovered from $H$. himantopus for the first time from the present host from Sindh region, hence making new host and new locality on record.

\section{Uvitellina sindhiensis species novum}

(Digenea: Cyclocoelidae:

Haematotrephinae) 
Figure 7-10, (Table 2).

Type Host:

Himantopus himantopus (L.) (Black-

winged Stilt (Charadriiformes:

Recurvirostridae).

\section{Material examined}

Present

Host:

Himantopus himantopus Black winged stilt.

Locality: Sindh (District Naushehro Feroze), Pakistan.

Date of collection: 05-iv-2018.

Site of infection: Body Cavity.

No. of parasites recovered: 14 out of 6 birds.

Prevalence: $100 \%$

Intensity: 2.33 .

Type Specimens: Holotype - 01 and Paratypes - 03. Other material: 10. Deposited in APRLMP, University of Sindh, Jamshoro. Etymology

The epithet of the present new species is given after the type locality, which is Sindh province, from where it is been recovered and introduced as new species to science, hence the name Uvitellina sindhiensis has been proposed.

\section{Description}

Body is large without spine anteriorly tapered and posteriorly wide and rounded in shape, measured 15.13 (15.4-14.86) long and 3.07 (3.64-2.5) wide in the middle of the body; oral sucker less developed and $0.33(0.42$ $0.24) \times 0.13(0.133-0.13)$ in size; ventral sucker absent; pharynx larger than oral sucker and wider relatively, measuring 0.45 $(0.46-0.45) \times 0.40(0.4-0.45)$ in size; testes rough and trigonal, anterior testes measured $1.0(1.02-0.98)$ long and $0.72(0.71-0.73)$ wider; posterior testes measured 0.99 (1$0.99)$ long and 0.99 (1.04-0.94) wide; ovary oval, pre-testicular and measured 0.45 (0.44$0.46)$ in length and $0.50(0.51-0.50)$ in width; genital pore post pharyngeal in position, opens at mid line of the pharynx; vitallaria always confluent posteriorly at lateral sides of caeca; cirus located at one side of the body; eggs spherical, measured 0.17 (0.24-0.11) long and 0.12(0.15-0.10) wide.

\section{Remarks}

In the present collection of trematodes infecting Black-winged stilt, a new species under the genus Uvitellina has been identified, which has been compared with its closed species including the two previously described species. Yamaguti [12] proposed eight species of the genus Uvitellina included $U$. pseudocotylea, recovered from Himantopus candidus (Long-legged plover) in Russia; however it is also recovered in the present study and find the difference in taxonomical features given in (Table 2).

The new species of the genus Uvitellina is different from previous species reported from various bird of Sindh, Pakistan, on the basis of morphometric characters. The genital pore is post pharyngeal opening in the center line of the pharynx and vitalline fields always united posteriorly placing in genus Uvitellina. Besides, the ovary of $U$. sindhiensis sp.n. is oval, pre-testicular and form triangle with testes in position, placing as new species in subfamily Haematotrephinae. On the basis of these characters the new species, Uvitellina sindhiensis has been proposed. 
Pure Appl. Biol., 9(1): 320-331, March, 2020

http://dx.doi.org/10.19045/bspab.2020.90037

Table 1. Comparison of morphometric characteristics of different species of the genus Uvitellina recovered from various host species (in mm)

\begin{tabular}{|c|c|c|c|c|c|c|c|c|c|c|c|}
\hline $\begin{array}{c}\text { Name of } \\
\text { organs }\end{array}$ & U. vanelli & U.teesae & $\begin{array}{c}U . \\
\text { megacaecatum }\end{array}$ & U. indica & $\begin{array}{c}U . \\
\text { dolfusi }\end{array}$ & U. adelphus & U. pseudocotylea & $\begin{array}{c}U . \\
\text { macroisophaga }\end{array}$ & $\begin{array}{c}U . \\
\text { kaniharensis }\end{array}$ & $\begin{array}{c}U . \\
\text { himantopi }\end{array}$ & U. iraquensis \\
\hline Host & $\begin{array}{l}\text { Himantopus } \\
\text { himantopus }\end{array}$ & $\begin{array}{l}\text { Himantopu } \\
\text { s } \\
\text { himantopus }\end{array}$ & $\begin{array}{l}\text { Himantopus } \\
\text { himantopus }\end{array}$ & $\begin{array}{l}\text { Lobivanellu } \\
\text { s indicus }\end{array}$ & $\begin{array}{l}\text { Vanellus } \\
\text { inereus }\end{array}$ & $\begin{array}{c}\text { Himantopus } \\
\text { leucocephallu } \\
\text { s }\end{array}$ & $\begin{array}{c}\text { Himantopus } \\
\text { acndidus } \\
\text { Charadrius } \\
\text { placidus }\end{array}$ & $\begin{array}{l}\text { Oxyechus } \\
\text { vociferous }\end{array}$ & $\begin{array}{c}\text { Glottis } \\
\text { nebularia }\end{array}$ & $\begin{array}{l}\text { Himantopus } \\
\text { himantopus }\end{array}$ & $\begin{array}{l}\text { Vanellus } \\
\text { leucurus }\end{array}$ \\
\hline Locality & Pakistan & Pakistan & Pakistan & India & Nanjing & Australia & $\begin{array}{l}\text { Russia, Turkistan, } \\
\text { Japan }\end{array}$ & California .USA & India & Ukraine & Iraq \\
\hline $\begin{array}{l}\text { Body } \\
\text { size }\end{array}$ & $\begin{array}{l}15.07(15.57- \\
14.56) \times 2.87 \\
(2.90-2.84)\end{array}$ & $7.89 \times 1.49$ & $\begin{array}{l}(6.482) 5.36- \\
8.25\end{array}$ & $\begin{array}{l}5.683- \\
7.656 \times \\
1.113- \\
1.536 \\
\end{array}$ & 14.000 & $8.100 \times 14.820$ & $6.5 \mathrm{v} 2.4$ & $7.8(6-9)$ & $\begin{array}{c}13.44- \\
16.128 x \times 2.88 \\
-3.84\end{array}$ & $\begin{array}{c}13,644 \times 15,1 \\
00\end{array}$ & $8,834 \times 10,459$ \\
\hline $\begin{array}{l}\text { Oral } \\
\text { sucker }\end{array}$ & $\begin{array}{c}0.14(0.14- \\
0.15) \times 0.39(0.49 \\
-0.29)\end{array}$ & 360 & $\begin{array}{l}(0.27) 0.32- \\
0.50\end{array}$ & $210 \times 326$ & -- & -- & None & 210 & $272-336$ & $\begin{array}{l}408(380- \\
450)\end{array}$ & $363(290-420)$ \\
\hline Pharynx & $\begin{array}{c}0.0 .34(0.30- \\
0.39) \times 0.41 \quad(0.40 \\
-0.42)\end{array}$ & 416 & Absent & $249 \times 345$ & 483 & 500 & $262 \times 331$ & $155(143-171)$ & $288 \times 355$ & $\begin{array}{c}383(370- \\
395)\end{array}$ & $323(295-345)$ \\
\hline Testes & $\begin{array}{c}\text { Ant. } 0.0 .86(0.83 \\
-0.90) \times 0.87 \\
(0.85-0.88) \\
\text { Post. } 0.84(0.90- \\
0.79) \times 0.81(0.85 \\
-0.79) \\
\end{array}$ & $433 \times 533$ & $\begin{array}{c}\text { Ant.0.38 }(0.33- \\
0.507) \times 0.501 \\
(0.391-0.724)\end{array}$ & $384 \times 268$ & $\begin{array}{l}955 \\
(920- \\
989)\end{array}$ & 690 & $661 \times 1,254$ & $461(414-628)$ & $528 \times 1,040$ & $\begin{array}{l}626(470- \\
710)\end{array}$ & $513(300-690)$ \\
\hline Ovary & $\begin{array}{c}0.41(0.38-0.45) \\
\times 0.43(0.45- \\
0.42)\end{array}$ & 299 & $\begin{array}{c}0.31-0.144 \\
(0.4405) \times \\
0.22-0.376 \\
(0.3143) \\
\end{array}$ & $210 \times 268$ & 529 & 350 & $319 \times 513$ & $191(142-242)$ & $320 \times 336$ & $\begin{array}{c}425(410- \\
485)\end{array}$ & $289(240-340)$ \\
\hline Egg & $\begin{array}{c}0.23 \\
0.300 .23) \times 0.1 \\
(0.11-0.09)\end{array}$ & $\begin{array}{l}145(136- \\
153) 55 \\
(50-59)\end{array}$ & $\begin{array}{c}0.131(0.13- \\
0.144) \times \\
(0.054)(0.05- \\
0.057) \\
\end{array}$ & $\begin{array}{c}145(136- \\
153) \times \\
55(50-59)\end{array}$ & 243 & $\begin{array}{c}175(170- \\
180) \times 75 \\
(70-80)\end{array}$ & $\begin{array}{c}147(134-159) 55 \\
(48-62)\end{array}$ & $\begin{array}{c}136(128- \\
143) \times 50-(43-57)\end{array}$ & -- & $\begin{array}{c}183(150- \\
195) \\
98(90-105)\end{array}$ & $\begin{array}{c}205(193-215) \\
72(63-88)\end{array}$ \\
\hline
\end{tabular}


Hattar et al.

Table 2. Comparison of morphometric characteristics of new species of the genus $U$ vitellina with its closely related species infecting various host birds, all measurements are given in $\mathbf{~ m m}$.

\begin{tabular}{|c|c|c|c|c|c|c|c|c|c|c|c|c|}
\hline $\begin{array}{c}\text { Name } \\
\text { of } \\
\text { organs }\end{array}$ & $\begin{array}{c}\text { Present } \\
\text { new } \\
\text { species }\end{array}$ & U.teesae & U.megacaecatum & U.indica & U.dolfusi & U.adelphus & $\begin{array}{c}U . \\
\text { vanelli }\end{array}$ & $\begin{array}{c}U . \\
\text { pseudocotylea }\end{array}$ & $\begin{array}{c}U . \\
\text { macroisophaga }\end{array}$ & $\begin{array}{c}\text { U. } \\
\text { kaniharensis }\end{array}$ & U. himantopi & U. iraquensis \\
\hline Host & $\begin{array}{l}\text { Himantopus } \\
\text { himantopus }\end{array}$ & $\begin{array}{l}\text { Himantopus } \\
\text { himantopus }\end{array}$ & $\begin{array}{l}\text { Himantopus } \\
\text { himantopus }\end{array}$ & $\begin{array}{l}\text { Lobivanellus } \\
\text { indicus }\end{array}$ & $\begin{array}{l}\text { Vanellus } \\
\text { cinereus }\end{array}$ & $\begin{array}{l}\text { Himantopus } \\
\text { leucocephallus }\end{array}$ & $\begin{array}{l}\text { Vanellus } \\
\text { vanellus }\end{array}$ & $\begin{array}{c}\text { Himantopus } \\
\text { candidus } \\
\text { Charadrius } \\
\text { placidus }\end{array}$ & $\begin{array}{c}\text { Oxyechus } \\
\text { vociferous }\end{array}$ & $\begin{array}{c}\text { Glottis } \\
\text { nebularia }\end{array}$ & $\begin{array}{l}\text { Himantopus } \\
\text { himantopus }\end{array}$ & $\begin{array}{l}\text { Vanellus } \\
\text { leucurus }\end{array}$ \\
\hline Locality & Pakistan & Pakistan & Pakistan & India & Nanjing & Australia & Veina & $\begin{array}{c}\text { Russia } \\
\text { Turkistan } \\
\text { Japan } \\
\end{array}$ & $\begin{array}{l}\text { California } \\
\text {.USA }\end{array}$ & India & Ukraine & Iraq \\
\hline $\begin{array}{l}\text { Body } \\
\text { size }\end{array}$ & $\begin{array}{c}15.13(15.4- \\
14.86) \\
3.07(3.64- \\
2.5) \\
\end{array}$ & $7.89 \times 1.49$ & $5.36-8.25(6.482)$ & $\begin{array}{c}5.683- \\
7.656 \times 1.113- \\
1.536\end{array}$ & 14.000 & $8.100 \times 14.820$ & 20,400 & $6.5 \times 2.4$ & $7.8(6-9)$ & $\begin{array}{c}13.44- \\
16.128 \times 2.88- \\
3.84\end{array}$ & $13,644 \times 15,100$ & $8,834 \times 10,459$ \\
\hline $\begin{array}{c}\text { Oral } \\
\text { sucker }\end{array}$ & $\begin{array}{c}0.33(0.42- \\
0.24) \\
0.13(0.13- \\
0.13) \\
\end{array}$ & 360 & $0.32-0.50(0.27)$ & $210 \times 326$ & None & None & None & None & 210 & $272 \times 336$ & $408(380-450)$ & $\begin{array}{c}363(290- \\
420)\end{array}$ \\
\hline Pharynx & $\begin{array}{c}0.45(0.46- \\
0.45) \\
0.40(0.4- \\
0.45) \\
\end{array}$ & 416 & Absent & $249 \times 345$ & 483 & 500 & 500 & $262 \times 331$ & $155(143-171)$ & $288 \times 355$ & $383(370-395)$ & $323(295-345)$ \\
\hline Testes & $\begin{array}{c}\text { Ant.1 } \\
(1.02-0.98) \\
0.72(0.71- \\
0.73) \\
\text { Post.0.99 } \\
(1-0.99) \\
0.99(1.04- \\
0.94)\end{array}$ & $433 \times 533$ & $\begin{array}{c}\text { Ant.0.33-0.507 } \\
(0.382) \times 0.391- \\
0.724(0.501)\end{array}$ & $384 \times 268$ & $\begin{array}{l}955 \\
(920- \\
989)\end{array}$ & 690 & 690 & $661 \times 1,254$ & $461(414-628)$ & $528-1,040$ & $626(470-710)$ & $513(300-690)$ \\
\hline Ovary & $\begin{array}{c}0.45(0.44- \\
0.46) \\
0.50(0.51- \\
0.50)\end{array}$ & 299 & $\begin{array}{c}0.31-0.144 \\
(0.4405) \times 0.22- \\
0.376 \\
(0.3143)\end{array}$ & $210-268$ & 529 & 350 & 350 & $319 \times 513$ & $191(142-242)$ & $320-336$ & $425(410-485)$ & $\begin{array}{c}289(240- \\
340)\end{array}$ \\
\hline Egg & $\begin{array}{c}0.17(0.24- \\
0.11) \\
0.12(0.15- \\
0.10)\end{array}$ & $\begin{array}{c}145(136- \\
153) \times 55 \\
(50-59)\end{array}$ & $\begin{array}{c}0.13-0.144 \\
(0.131) \times \\
0.05-0.057 \\
(0.054)\end{array}$ & $\begin{array}{c}145(136- \\
153) \times \\
55(50-59)\end{array}$ & 243 & $\begin{array}{c}175(170-180) \\
\times 75(70-80)\end{array}$ & $\begin{array}{c}175(170- \\
180) \times 75 \\
(70-80)\end{array}$ & $\begin{array}{c}147(134-159) \\
\times 55(48-62)\end{array}$ & $\begin{array}{c}136(128- \\
143) \times 50-(43- \\
57)\end{array}$ & - & $\begin{array}{c}183(150- \\
195) \times 98(90- \\
105)\end{array}$ & $\begin{array}{c}205(193- \\
215) \times 72(63- \\
88)\end{array}$ \\
\hline
\end{tabular}



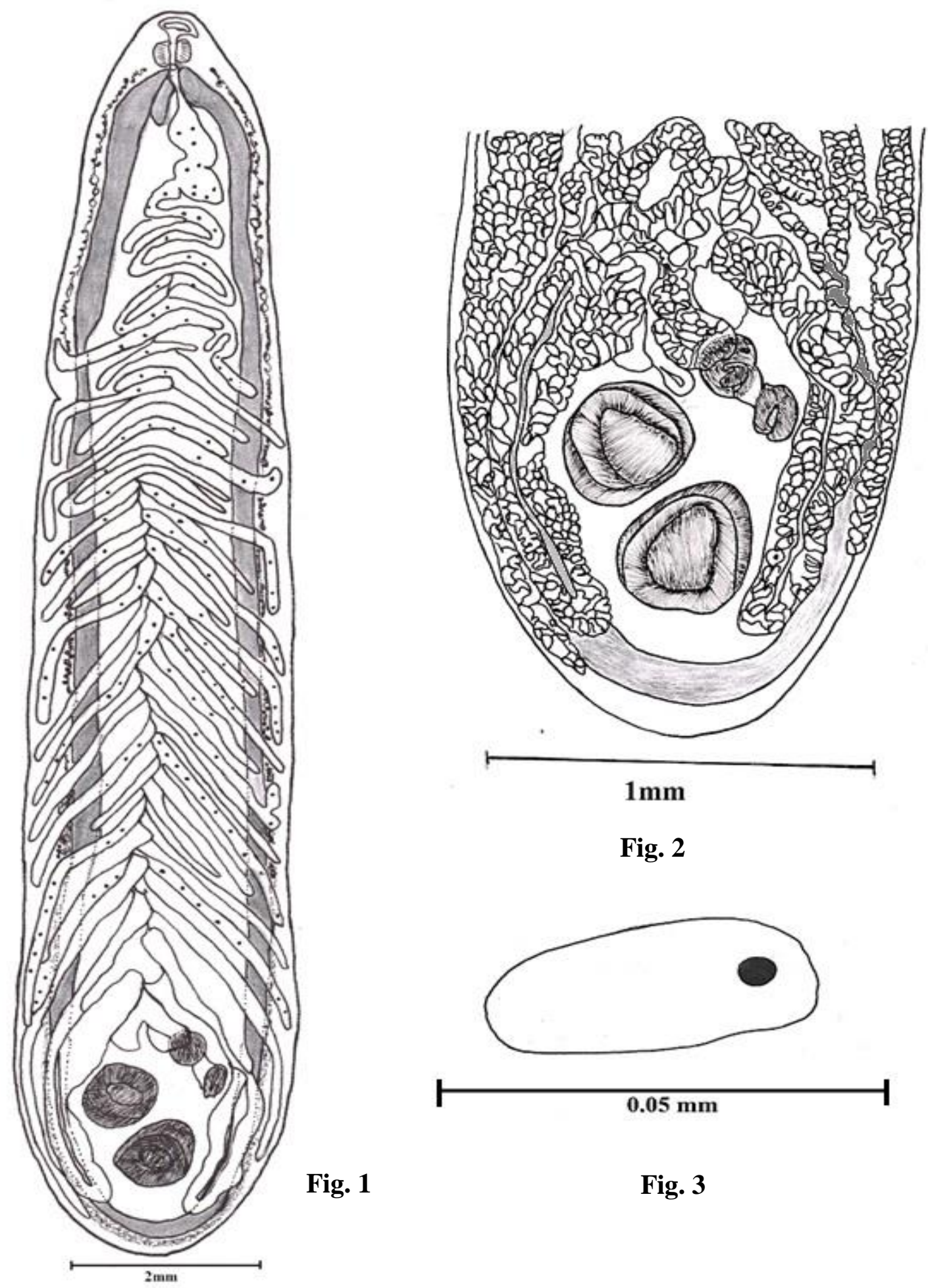

Fig. 2

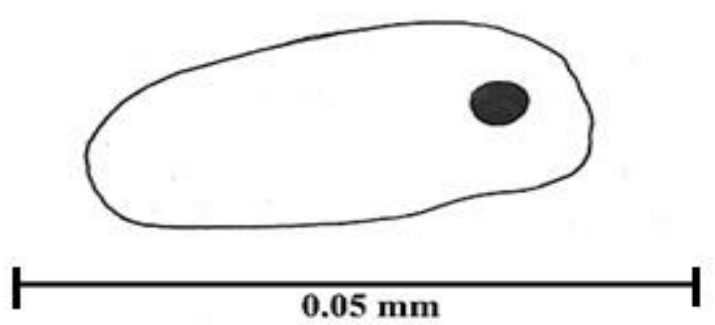

Fig. 1

Fig. 3

Figures 1-3. Uvitellina vanelli (Rodulphi, 1819): 1. Whole specimen, 2. Posterior portion of the body showing position of gonads and vitalleria, 3. Mature egg 
Hattar et al.
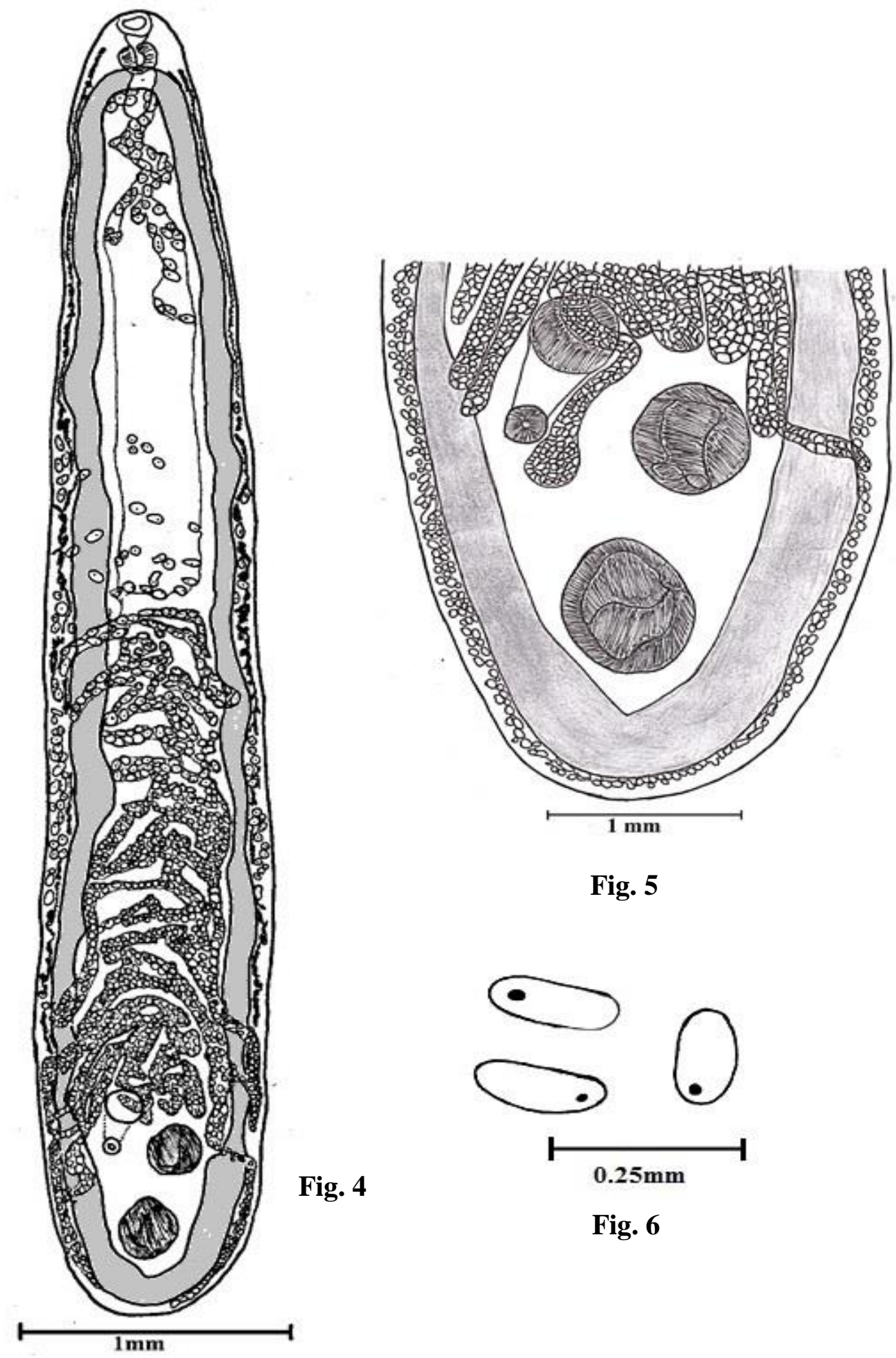

Fig. 5

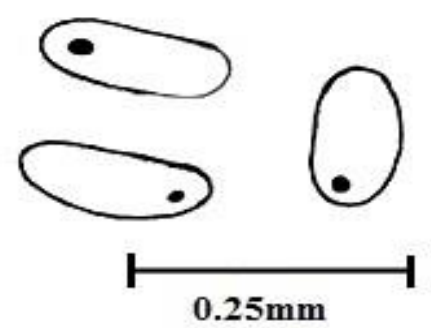

Fig. 6

Figures 4-6. Uvitellina pseudocotylea Witenberg, 1923: 4. Whole specimen, 5. Posterior portion of the body showing position of gonads and vitalleria, 6 . Mature eggs 

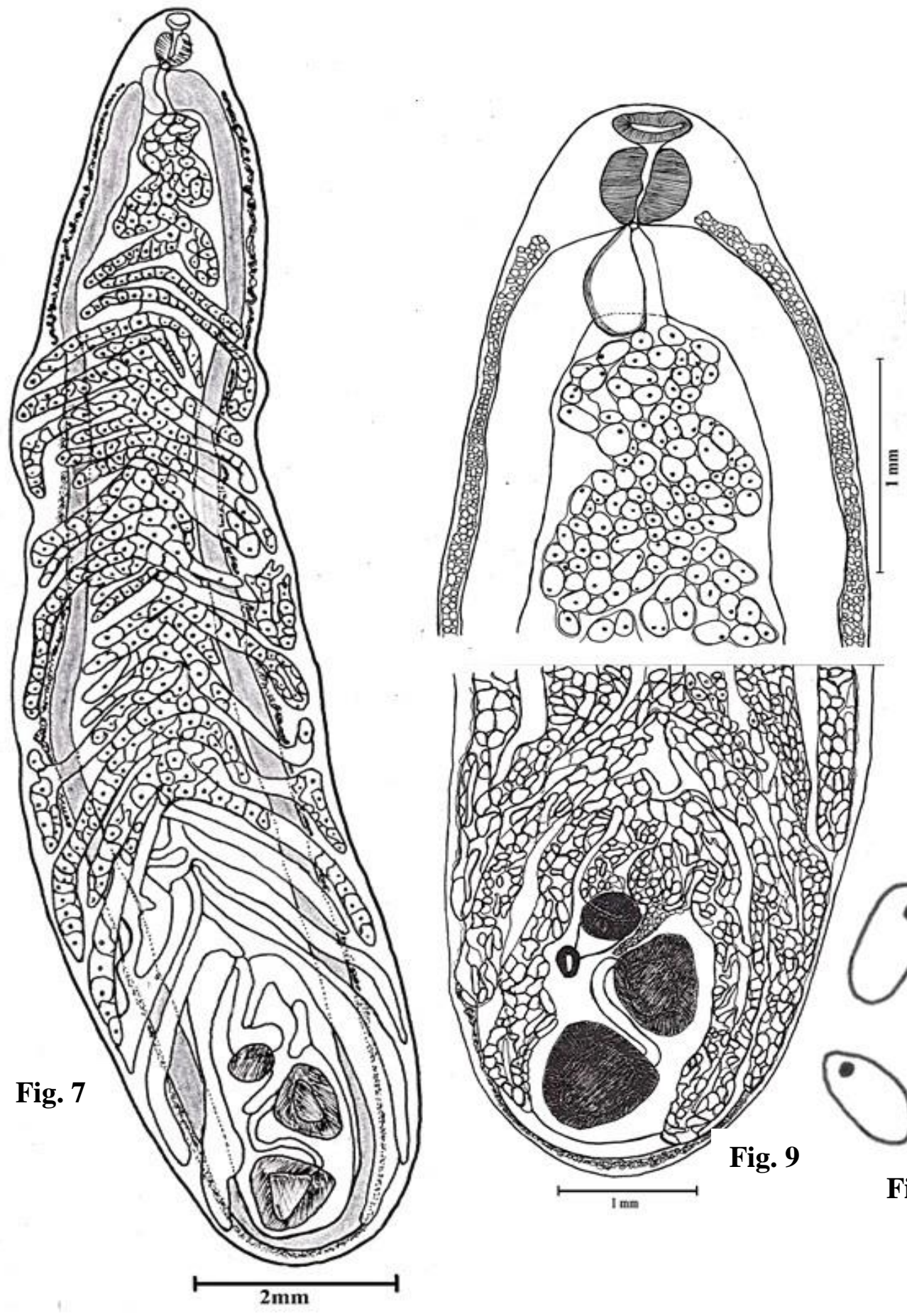

Fig. 8
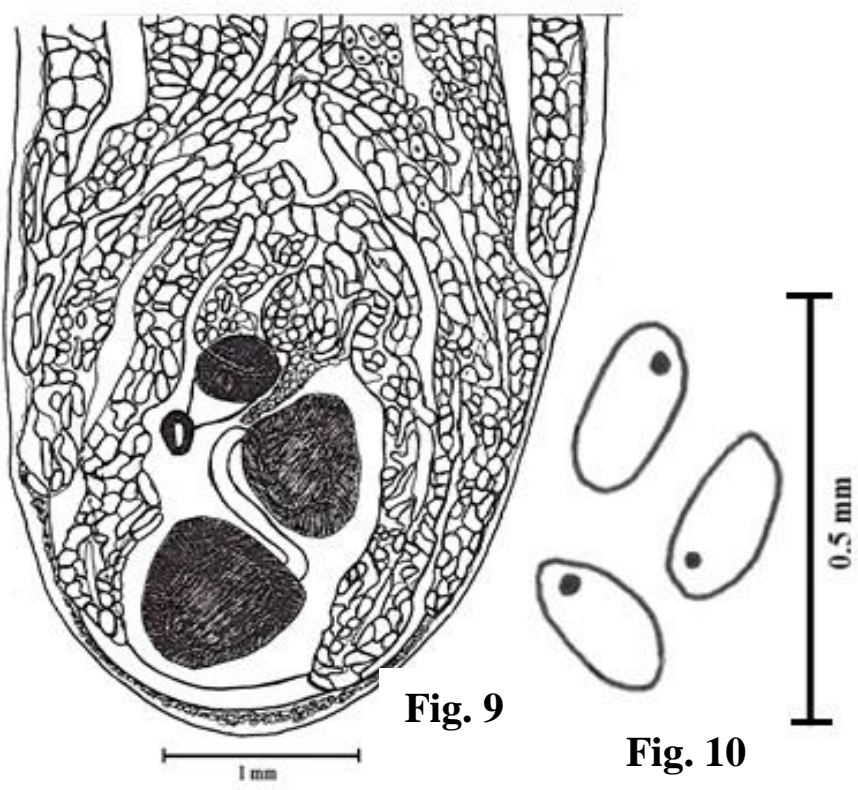

Fig. 10

Figures 7-10. Uvitellina sindhiensis sp.n. 7. Whole specimen, 8. Anterior portion of the body showing weak oral sucker and cirus pouch, 9. Posterior portion of the body showing position of gonads and vitalleria, 10. Mature eggs 


\section{Discussion}

The trematode family Cyclocoelidae Stossich, 1902 consists of six subfamilies are latest recognized largely based on the orientation of the ovary relative to the testes. Subfamily Cyclocoelinae [15] has a characteristic of the ovary, located between testes (inter-testicular) make a triangle with the testes; Haematotrephinae [16] has the orientation of the ovary is located at upper part of anterior testes (pre-testicular) to opposite to the anterior testis forming a triangle with the testes; in subfamily Ophthalmophaginae [17] the ovary is posttesticular forming a straight line with the testes; in Hyptiasminae [16], the ovary is inter-testicular and the testes are tandem to nearly tandem; in Skrjabinocoelinae [18], the ovary is inter-testicular and the testes are nearly side by side; in Szidatitreminae [18] the position of the ovary ranges from being post-testicular to opposite to the posterior testis forming a triangle with the testes. On the basis of these characteristics, the species in genus Uvitellina in the present study were described.

The family Cyclocoelidae has commonly related and dependable features which are useful to determine the subfamilies and its genera. Most of the species lack an oral sucker and few are known to have it but less developed, and these contribute to broad range of variation seen in detailed measurement as well as its location [19, 20]. Dronen and Blend [21] described major three features to describe genera and subfamilies of family Cyclocoelidae, including posterior extension of vitalline fields may be reaching posteriorly, position of ovary in relation to testis and location of the genital pore related to the pharynx.

In the region, especially in Pakistan, the studies on this family and genera have been remained a controversial in identification, hence many of the species names are synonymized and close similarities within the species always have shown a confusion in determination of cyclocoelid species. However Dronen and Blend [21] have made an effort to remove the confusion with in the species morphology, which here remained supportive measure to identify the genus and its species.

The genus Uvitellina was first introduced by Wittenberg in 1923, reported from various birds of the order Charadriiformes, under the family Cyclocoelidae and subfamily Haematotrephinae. The family Cyclocoelidae was known accidental parasites of various birds; until parasites found in respiratory system, especially lungs and air sac [22-26]. Previously, Uvitellina indica was collected from Vanellus indicus was described from India [27], but under Lobivanellus indicus, later it was redescribed under the genus Uvitellina with $U$. kaniharensis [11], which was recovered from Tringa nebularia, U. keri [12] from V. cinereus and U. tageri [12] and $U$. vanelli [7] from $V$. vanellus in Japan, $U$. macroisophaga [28] from Charadrius vociferious in U.S. and U. magniembria [29] from Himantopus candidius in Russia. Johnston [30] elaborated Haematotephus adelphus from Himantopus leuocephalus however Witenberg [29] has transferred in to genus Uvitellina as $U$. adelpha, because vitalline fields of this species were reaching posteriorly and connecting to each other. Yamaguti [10] kept this species in the genus Haematotephus but the original description of it strongly showed the vitalline fields were reaching posteriorly and hence it was designated as the species of genus Uvitellina [21-25].

In the region of western to southern-east including Pakistan, U. iraquensis was reported from Iraq, infected to $V$. leucurus [31] and two species were reported from Pakistan including $U$. teesae from Butastur teesae [32] and $U$. megacaecatum from Himantopus himantops [6]. Dronen and Blend [21] have resescribed $U$. teesae Dharejo et al. [32] under 
the genus Haematotrephus on the basis of incomplete description and synonymized it as H. teesae. Dharejo et al. [32] have illustrated the vitalline field as vitallaria occupied extracaecal lateral fields, suggested not extended posteriorly, which is the key character of the later genus [32].

The present study hence is the connection of more fauna of trematodes of marshy and semi aquatic birds include three more species in Sindh region. It deals with the trematode infection and burden on host and the prevalence of trematodes seem to be higher in blackwinged stilt, $H$. himantopus with $U$. vanelli found more noticeable species in the host. Presently, $U$. vanelli and $U$. pseudocotylea were reported from the present host for the first time in the country hence making new host for both the species on record and a new species with the evident morphological differences and comparison (Table 2 and 3) with known species, following the key given by Dronen and Blend [21] was introduced in the region and proposed as $U$. sindhiensis sp.n.

\section{Authors' contributions}

Conceived and designed the experiments: S Naz \& NA Birmani, Performed the experiments: FA Hattar \& NA Birmani, Analyzed the data: FA Hattar \& S Naz, Contributed materials/ analysis/ tools: S Naz, Wrote the paper: S Naz \& FA Hattar.

\section{Acknowledgments}

Authors acknowledge Higher Education Commission (HEC) for funding the Research Project 20-4514 under which the present study was under taken.

\section{References}

1. Pierce RJ (1985). Feeding methods of stilts (Himantopus spp.). New Zealand J Zoo 12: 467-472.

2. Arnall L \& Keymer IF (1975). Bird diseases: an introduction to clinical diagnosis and treatment of diseases in birds other than poultry. Bailliere Tindall, London. pp 528.

3. Baker AJ \& Thomas G (2003). Avocets and Stilts. In Perrins C (editor). The Firefly
Encyclopedia of Birds: Firefly Books 242243. ISBN: 1-55297-777-3.

4. Goriup PD (1982). Behaviour of Blackwinged Stilts. British Birds 75: 12-24.

5. Murai E, Sulgostowska T, Matskasi I, Meszaros F \& Molnar K (1983). Parasitic helminths of vertebrates (fishes, amphibians, reptiles and birds) in the Hortobagy National Park. Natural History of the National Parks of Hungary 2: 15-30.

6. Siyal B, Das SN \& Ghazi RR (2016). Uvitellina megacaecatum sp.n. (Trematoda: Cyclocoelidae) from the intestine of Himantopus himantopus (Black winged stilt) in Naushehro Feroze, Sindh, Pakistan. J Ento Zool Stud 4 (6): 327-330.

7. Rudolphi CA (1819). Enterzoorum synops is cui acceduntmantissa duplex et indices 1 ocupletis simi: Berolina. pp 811.

8. Bashkirova EI (1950). Family Cyclocoelidae Kossack, 1911. Osnovy Trematodologii 4: 329-493.

9. Dubois G (1965). Notes sur les Cyclocoelidae Kossack, 1911 (Trematoda). Revue Suissse de Zoologie 72: 413-427.

10. Yamaguti S (1971). Synopsis of Digenetic Trematodes of Vertebrates: Keigaku Publishing Company, Japan 2: 1575.

11. Gupta PD (1958). Haematotrephus (Uvitellina) kaniharensis n.sp. (Trematoda: Cyclocoeliidae Kossack, 1911) from Allahabad. Indian J of Helminthol 10: 1-5.

12. Yamaguti S (1933). Studies on the helminth fauna of Japan. Trematodes of birds, reptiles and mammals. Japanese $J$ Zool 1(5): 1-134.

13. Fernandes BMM (1976). Sobre as espéciesbrasileiras da família Cyclocoelidae Kossack 1911 (Trematoda, Cyclocoelidae). Memorias do Instituto Oswaldo Cruz 74(3-4): 289-294.

14. McNeill R, Tulio DM, Casanova B \& Villeneuve A (1995). Trematode parasitism as a possible factor in over-summering of greater yellow-legs (Tringa melaneuca). Ornitologia Neotropica 6: 57-65.

15. Stossich M (1902). Monostomum mutabile Zeder e le sue forme affini. Bollettino della 
Societ'a Adriatica di Scienz Naturali in Trieste 21: 1-40.

16. Dollfus R (1948). Sur deux monostomes (Cyclocoelidae) pourvus d'une ventrose ventral. Observations sur la classification des Cyclocoeloidea, Henry A (1923): liste de leurs hotes, rêpartition géographiques. Ann Parasitol Hum Comparée 23: 129199.

17. Harrah EC (1922). North American monostomes primarily from freshwater hosts. Illinois Biological Monographs 7: 225-324.

18. Dronen NO (2007). Revision of the family Cyclocoelidae Stossich, 1902 with the proposal of two new subfamilies and the description of a new species of Morishitium Witenberg, 1928 from the common snipe, Gallinago gallinago, from Texas, USA. Zootaxa 1563: 55-68.

19. Gibson DI, Jones A \& Bray RA (2001). Keys to the Trematoda. CAB International and Natural History Museum, London 1: 521.

20. Dronen NO \& Tkach VV (2013). Description of a new species of Uvitellina Witenberg, 1923 (Cyclocoelidae: Haematotrephinae), from the black-winged stilt, Himantopus himantopus (Charadriiformes: Recurvirostridae) from the Ukraine. Comparative Parasitol 80: 179-185.

21. Dronen NO \& Blend CK (2015). Updated keys to the genera in the subfamilies of Cyclocoelidae Stossich, 1902, including a reconsideration of in Szidatitreminae Dronen, 2007. Zootaxa 4053(1): 1-100.

22. McLaughlin JD (1975). Experimental studies on the life cycle of Cyclocoelum mutabile (Zeder) (Trematoda: Cyclocoelidae). Canad J Zool 54: 48-54.

23. Bauer C (2006). Helminthosen des Nutzgeflügels. In Schnieder S (editor). Veterinär medizinische Parasitologie $6^{\text {th }}$ edn. Parey S: 606-607.

24. Kanev I, Radev V \& Fried B (2002). Family Cyclocoelidae Stossich, 1902. In
Gibson DI, Jones A, Bray RA (Editors): Keys to the Trematoda. Volume 1. CABI Publishing and The Natural History Museum, London 131-145.

25. Hintzen J, Thielebein J, Daugschies A \& Schmäschke R (2016). Trematodes from the Northern Lapwing, Vanellus vanellus (Charadriidae), from Central Germany. Parasitol Res. DOI 10.1007/s00436-0165330-9.

26. McDonald ME (1981). Key to Trematodes reported in Waterfowl. Resource Publication 142: US Department of the Interior, USA. Fish and Wildlife Service: Washington DC, pp 156.

27. Siddiqi AH \& Jairajpuri MS (1962). Uvitellina indica n.sp. (Cyclocoelidae) from a red-wattle lapwing, Lobivannellus indicus (Boddaert). Z Parasitenkd 21: 212214.

28. Hannum CA \& Wilson BE (1934). Uvitellina macriosophaga n.sp. from the kill deer. Trans Am Microscopial Soc 53(3): 245-250.

29. Witenberg GG (1923). The trematodes of the family Cyclocoelidae and a new principle of their systematics. Trudy Gosudarstvennogo Institute Ceksperimental' nocei Veterinarii 1: 84141.

30. Johnston SJ (1917). On the trematode of Australian birds. J Proc Royal Soc NSW 50: 187-261.

31. Dronen NO, Ali AH \& Al-Amura MFA (2013). Description of a new species of Uvitellina Witenberg, 1923 (Cyclocoelidae: Haematotrephinae), from the White-Tailed Lapwing, Vanellus leucurus (Lichtenstein) (Charadriiformes: Charadriidae) from Iraq. Comparative Parasitol 80(1): 9-16.

32. Dharejo AM, Bilqees FM \& Khan MM (2007). Uvitellina teesae new species (Digenea: Cyclocoelidae) from liver of White-eyed buzzard Butastur teesa (Accipitridae) in Hala, Hyderabad, Sindh, Pakistan. Pak J Zoo 39: 385-387. 